\title{
Why style matters? \\ Some noises and barriers for textual information processing
}

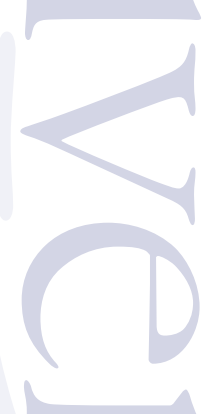

\author{
Helena Vičič, Red Tree Heritage
}

Veliko besed je bilo povedanih o uporabi besedil pri predstavitvah dediščine, zlasti za panoje in nalepke na muzejskih razstavah. Ugotovljeno je bilo, da akademski jezik ni primeren za posredovanje informacij obiskovalcem, zlasti kadar sta ciljni skupini otroci in družine. Poleg tega, ko gre za besedila na panelih in nalepkah, imajo vse ciljne skupine koristi od interpretativnega pristopa. Prispevek bo poskušal preučiti nekatere »šume (v vsakem smislu), ki lahko odvrnejo obiskovalca od branja in nekatere ovire, ki onemogočajo uspešno obdelavo informacij, in tako zmanjšujejo zanimanje za pisano besedo.

Ključne besede: interpretacija, interpretativna besedila, dediščinske lokacije, psihologija obiskovalcev, vedenje obiskovalcev.

Many words have been exchanged on behalf of the use of texts in heritage settings, especially for panels and labels in museum exhibitions. It has been acknowledged that academic language is not appropriate way to communicate information to the visitors, especially when children and families are targeted. Moreover, when it comes to the text on panels and labels, all target groups benefit from the interpretive approach. This paper will try to examine some 'noises' (in every kind of sense) that can distract a visitor from reading and some barriers that disable successful information processing and thus impairs an interest in a written word.

Keywords: interpretation, interpretive text, heritage sites, psychology of visitors, visitors' behaviour

W e often think that our visitors pay much more attention to the text itself, as they actually do. The comparison between the amount of work and money that is invested in the textual media and how little they are attended, is often disappointing.

Although the concept of accessibility understands barriers more in a physical sense, which is a very welcome and important step towards the inclusive society, we rarely think of our texts as inaccessible in intellectual sense. Leisure activities, that a visit to a heritage site often is, create different circumstances and are practiced by people with the aim to satisfy specific needs. It is our duty to understand our audiences and their processes while hosting them in our premises.

\section{To read or not to read?}

Many researches indicate, that the majority of people do not come to heritage sites primarily to learn. Socialising and group bonding usually appears on the top of the list of reasons, followed by relaxation, experiencing new things and only then gaining new information (Fáilte Ireland 2009, 16). The question is how this influences their mental abilities for reading and what text should interpretation provide in order for it to be attended. Many researchers encourage in- 
terpreters to devise means that contribute to the social exchange between visitors (Simon 20I0).

In average people spend less than Io seconds at one sign and read only about $10 \%$ of exhibits (Caputo, Brochu and Lewis 2008, 6). Whatever media visitors encounter, they subconsciously calculate whether is it worth attending or not. This cost-benefit calculation is called Fraction of selection. Namely, if the degree of effort that one invests into the reading, appears higher than the reward expected, they mainly choose not to attend (Zimmerman, Gross and Buchholz 2008, 24). This decision is taken very quickly, based on the Drawing power of a medium (Sandifer 2003). As a visitor first encounters a medium, creates an overall impression from the distance. If a medium possesses the so called Attraction power, a visitor approaches closer and quickly examines the medium in a couple of seconds. Usually such medium must be visually attractive. When a visitor starts reading, at first only scanning the text, but sometimes also reading in more detail, then such medium possesses a Holding power. When a visitor, instructed by the text, is looking around the place for original phenomena that were described or tasks to which the text invited, such medium has an Engagement power.

However, considering that people visiting heritage sites are interested in the heritage, why is the attendance to panels and labels so low? Why they so often conclude that the reward is not worth an effort? Moreover, the research also show that the majority of visitors to the heritage site is traditionally well educated and work in managerial and professional positions (Booth et al. 2017). Why then the reading presents such a challenge?

\section{Our brain is a busy place}

Every presentation intended to public shall be planned in respect to human cognition. Working memory capacities and limitations play an important part in individual's information processing, understanding and learning. Many theories argue about different bottlenecks in our brain, which permit through only certain senso- ry inputs (Baddeley 2007; Broadbent 1958; Paivio 1990). When processing two or more tasks of the same type, one or another will likely get attenuated or impaired. Text is verbal information, which is processed in the Phonological loop (Baddeley 2007), a brain centre in charge of reading, listening, talking or recalling stored verbal information from the memory. According to Dual-Coding Theory (Paivio 1990) dealing with two or more tasks of the same modality, in our case verbal information, cause a bottleneck effect. Knowing this, one can realise how difficult task is reading, while the Phonological loop is also dealing for example with listening to a distant audio track or to other people in the room or when our brain is dealing with many other thoughts.

In Cognitive Load Theory (Sweller 20II) three types of load are recognised: intrinsic cognitive load, which is intrinsic to the nature of the task (e.g. difficulty of concepts presented, vocabulary level, terminology, genre, etc.); extraneous cognitive load, which is posed by the manner of presentation (like amount and distribution of text, design, fonts, etc.) and germane cognitive load, which depends on the individual's cognitive processes, based on the pre-existing schemas and knowledge and working memory capacities.

While interpreters have no immediate influence on the last category of cognitive load, much can be done for the reduction of intrinsic cognitive load. Especially if we expect audiences, that possess little if any knowledge about the subject matter, a narrative text, which describes events and relations in a causal or thematic chain (Wolfe and Mienko 2007), would increase learning. For more knowledgeable individuals might be offered additional expository text (Wolfe and Mienko 2007), which describes structures and processes. Other general guidelines recommend using a simple, emotive and descriptive language, preferably on the level of IO-I2 years of age, with avoiding specific terminology, with presenting only the most important facts, etc.

In order to avoid unnecessary extraneous load, the design should allow to break out the 
text on layers and short paragraphs, make a use of subtitles, use an appropriate font size and spacing, corresponding colours and background. Since the article is not aiming to offer extensive guidelines, a reader is encouraged to peruse other sources for interpretive writing.

In decisions how many and which facts to include in the text, is particularly valuable the finding that people find hard to remember more than a certain number of ideas at the same time. The 'magical number' has decreased from five to nine ideas ( $7 \pm 2$ ), what Miller (Miller 1956 , 8I) discovered in 1965 onto three to seven ideas $(5 \pm 2)$ suggested by Ham for the people is $2 \mathrm{I}^{\mathrm{st}}$ century (Ham 2016, 28).

However, there are not cognitive capacities that divert us from reading. There are many theories that explain the physical, social and personal context, in which visitors try to pursue their various interests and needs.

\section{Visit is a social act}

During a visit, a great part of our attention goes to the surroundings and to other people. Full of impressions, especially if visiting for the first time, people examine the place and enjoy visual impressions. In the physical context (Falk and Dierking 2016) of the visit, visitors need to first find their way around, they try to select the parts of the content that are more interesting or relevant to them, on their way they are searching for facilities such as restrooms or refreshments, and nevertheless, they are concerned about the time. It has been proven for museum settings that no matter how large is the place or how many exhibitions a museum offers, in average people allocate one and a half hour to a single visit (Falk and Dierking 2016, 133), while a big museum contains as much text as one could read for days!

Most people come to heritage sites as part of a social group, with families or friends (Falk and Dierking 2016, I48). They would concern about their needs and behaviour, for instance, parents usually care for children's interests, learning opportunities and how can they provide also fun for them. During the visit, especially if the premises are crowded, their attention goes also to other people, sometimes due to the salient behaviour or due to the intrinsic human interest in other people.

Not all, that one experiences during the visit of heritage sites, has been described and yet it is obvious, what a variety and high number of elements occupies one's thoughts and how small are the chances for the attendance to the activity such as reading, which requires strong focus and vacant mental capacities. Naturally, humans are in power to consciously control and direct their actions to some extent, so one can choose to read or not to read at any time, but then again he or she would choose to read if a reward for the action is promising enough and the effort not too high.

\section{Does it have to do with $m e$ ?}

When the visitors are briefly scanning labels and panels, they are looking for words, that are familiar to them. In pursuing our interests and self-actualisation needs (Maslow 1943, 370), we are more attracted to the topics of which we already possess some knowledge or experiences. What proved especially effective with the readers are the three principles: Provoke - Relate - Reveal, by which a visitor is provoked to feel, think or do something, but prior to any such action, he or she must see the relevance with his or her own world: knowledge, experiences, beliefs, values or interests. When interpretation invokes curiosity or emotions or resonance, one's focal attention starts dealing with the subject matter in a short-term memory (Fennis and Stroebe 2010, 50), which is a pre-condition for any active consideration and also meaning-making.

\section{Conclusion}

Upper listed aspects are only the few from the vast field of psychological and sociological theories that are explaining the attitude towards labels and panels. Reading of online content, books and brochures is usually performed under different conditions and thus not a subject to this paper. 
Fortunately, much is written about the solutions for overcoming these barriers. Intellectual accessibility deserves much more serious consideration, especially if the heritage sites would like to increase visitation or attract more diverse audiences, also marginal groups, and especially if what they have got to share, conveys important messages for the whole society.

\section{Povzetek}

Članek polemizira odnos obiskovalcev do informativnih in interpretativnih besedil na tablah in panojih, ki so po večini manj obiskano sredstvo interpretacije. Raziskave kažejo, da obiskovalci v povprečju preberejo le okoli ro procentov besedil. Obiskovalci vsakokrat podzavestno tehtajo, kateri tekst se splača brati in ali obeta branje ustrezno nagrado. Razloge za takšen odnos gre iskati v psiholoških in socioloških teorijah. Po eno strani so zmožnosti obiskovalčeve kognicije na muzejskih razstavah ali v naravnem okolju drugačne kot v domačem ali delovnem okolju, saj možgani procesirajo veliko različnih dražljajev, ki se včasih izključujejo. Tako prihaja do kognitivne obremenitve, ki ne podpira koncentriranega branja besedil. Po drugi strani pa potrebe obiskovalcev na takšnih lokacijah pogosto izključujejo učenje kot primarno dejavnost. V ospredju so druženje, sprostitev in nova doživetja.

\section{Summary}

The article investigates the attitude that visitors to the heritage sites perform towards interpretive panels and labels, namely towards text. According to the research, in average only ro percent of text is actually read. According to Fraction of selection model, visitors attend to a panel, if the expected reward for reading is higher than the effort invested. The reasons for such behaviour have been found in psychological and sociological theories. The first suggest that visitor's cognitive capacities in leisure environment differ from the normal and that they are often overloaded. On the other hand, people often visit as a part of a group of other people, to which goes a great part of attention. Learning per se is namely not the main motivation for visiting heritage sites.

\section{References}

Baddeley, A. 2007. Working memory, thought, and action. Oxford psychology series Vol. 45 . Oxford: Oxford University Press.

Booth, K., J. O'Connor, A. Franklin and N. Papastergiadis. 2017. "It's a Museum, But Not as We Know It: Issues for Local Residents Accessing the Museum of Old and New Art". Visitor Studies 20 (I): 10-32.

Broadbent, D. 1958. "Effect of noise on an 'intellectual' task". The Journal of the Acoustical Society of America 30 (9): 824827.

Caputo, P., L. Brochu, and S. Lewis. 2008. Interpretation by design: graphic design basics for heritage interpreters. InterpPress,

Falk, J. H. and L. D. Dierking. 2016. The museum experience revisited. Lopndon and New York: Routledge.

Fennis, B. M. and W. Stroebe. 2010. The psychology of advertising. Hove, New York: Psychology Press.

-

Ham, S. H. 1992. Environmental interpretation: a practical guide for people with big ideas and small budgets. Golden, Colorado: North American Press.

Fáilte Ireland. 2009. Sharing our Stories: Using Interpretation to Improve the Visitors' Experience at Heritage Sites. Dublin: Fáilte Ireland.

Maslow, A. H. 1943. "A theory of human motivation". Psychological review 50 (4): $370-396$.

Miller, G. A. 1956. “The magical number seven, plus or minus two: Some limits on our capacity for processing information". Psychological review 63 (2): 81-97.

Paivio, A. 1990. Mental representations: $A$ dual coding approach. Oxford: Oxford University Press.

Sandifer, C. 2003. „Technological novelty and open-endedness: Two characteristics of interactive exhibits that contribute to the holding of visitor attention in a science museum. "Journal of research in science teaching 40 (2): I21-137. 
Simon, N. 2010. The participatory

museum. (Museum 2.0 blog). http://

museumtwo.blogspot.com/search/label/ participatory\%2omuseum

Sweller, J. 201r. "Cognitive load theory." In The psychology of learning and motivation: Vol.

55. The psychology of learning and motivation: Cognition in education, edited by Jose P.

Mestre and Brian H. Ross, 37-76. San Diego: Elsevier Academic Press.

Wolfe, M. B.W., and J. A. Mienko. 2007.

"Learning and memory of factual content from narrative and expository text." British Journal of Educational Psychology 77 (3): $54 \mathrm{I}-564$.

Zimmerman, R., M. Gross and J. Buchholz. 2008. Creating Exhibits that Expand the Imagination. Interpret Wales, workshop material. University of Wisconsin-Stevens Point. Better Visitor Center Workshop.

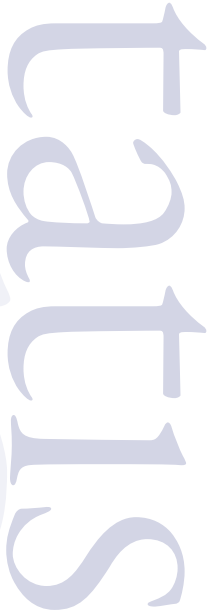

